MUTENKO H. V. ${ }^{1}$, OSTASH B. O. ${ }^{1}$, ROTHBALlER M. $^{2}$, WEISS A. ${ }^{2}$, SCHMID M. ${ }^{2}$, HARTMANN A. ${ }^{2}$, FEDORENKO V. O. ${ }^{1 凶}$

${ }^{1}$ Ivan Franko National University of Lviv,

Ukraine, 79005, Lviv, Hrushevskoho, 4

${ }^{2}$ Research Unit of Microbe-Plant Interactions, Helmholtz Centre Munich-German research Center for

Environmental Health,

Germany, Neuherberg

凶viktor.fedorenko@Inu.edu.ua, (032) 239-44-07, (032) 239-44-75

\title{
MICROBE-PLANT INTERACTIONS BETWEEN STREPTOMYCES AND MODEL AGRICULTURAL PLANTS - HORDEUM VULGARE AND LYCOPERSICON ESCULENTUM (MICROTOM)
}

\begin{abstract}
Aim. Microbe-plant interactions (MPI) constitute an important aspect of ecology because of their significant influence on plant's ability to withstand abiotic stress and infection. In comparison to proteobacteria and bacilli, the roles of streptomycetes in MPI remain poorly studied. Here, we elucidate some aspects of MPI between two model plant species, Hordeum vulgare and Lycopersicon esculentum, and several strains of Streptomyces lividans 1326 and S. ghanaensis ATCC14672. Methods. Microbiology, microscopy and molecular genetics were combined to reveal the MPI. Results. We demonstrate the colonization of $H$. vulgare and $L$. esculentum roots by different strains of S. ghanaensis deficient in production of either the antibiotic moenomycin or signaling molecule of the $\gamma$-butyrolactone type. The treatment of $H$. vulgare seeds with $S$. lividans spores increased the root biomass. Plants treated with 1,4-butyrolactone had no positive influence on plants, at milimolar concentrations this compound inhibited the root and shoot growth of L. esculentum. Conclusions. Roots of two mono- and dicot plants are colonized by Streptomyces; reporter gene uidA is useful to monitor the colonization. Under our experimental conditions the ability to colonize plants by streptomycetes was not affected by the deficiency in antibiotic or butenolide production.

Keywords: Streptomyces ghanaensis, moenomycinA, low-molecular weight signal compounds, root colonization.
\end{abstract}

Members of the actinobacterial genus Streptomyces, as soil dwellers, are imprescriptible constituents of ecosystems. They excrete hydrolytic enzymes and bioactive compounds displaying various activities, including (but not limited to) metal- chelating, antibacterial and antifungal ones [1]. Through production of these substances streptomycetes can promote plant growth, facilitate roots colonization by nodule-forming bacteria and protect plants against phytopathogens [2-7]. Although ubiquity of streptomycetes in soil and rhizosphere is well-documented, there is little data on how secondary metabolism of the former shapes their ability to colonize plants. Most of Streptomycescentered research has been done on model plant Arabidopsis thaliana. Particularly, colonization of A. thaliana roots by Streptomyces lividans was shown to provide protection of the former against fungal infection [8]. Recently A. thaliana colonization by endophytic streptomycetes has been reported as well as their responses to plant hormones [9]. These and other studies support the assumption that Streptomyces spp. can be important players in plant ecology.

In our work we decided to depart from studies on A. thaliana and focus on interaction of Streptomyces with agriculturally important plants. Particularly, monocot Hordeum vulgare and dicot Lycopersicon esculentum (Microtom) have been chosen. As bacterial partners we picked S. lividans strains because of proven ability to colonize plant roots. S. ghanaensis has also been included in the study; a collection of mutants for this species is available allowing us to address the roles of secondary metabolites in interactions with plants. The research was focused on three topics. First, we wanted to demonstrate that the streptomycetes under study indeed colonize plant roots and are able to produce antibiotics in situ. Second, effects of Streptomyces on plant growth were studied under different experimental setups. Third, we studied whether streptomycetes hormones of butenolide type, either

\footnotetext{
${ }^{\circ}$ MUTENKO H.V., OSTASH B.O., ROTHBALLER M., WEISS A., SCHMID M., HARTMANN A., FEDORENKO V.O.
} 
endogenously produced or artificially added, affect plants. The last research line was prompted by the fact that the root colonization intensity and pathogen inhibition by several non-streptomycetes depend on the production of low-molecular weight signaling compounds, LMWSC [10]. Butyrolactones and butenolides in streptomycetes are essential for secondary metabolism and morphogenesis $[11,12]$, yet their influence on other bacteria or plants was not studied.

\section{Materials and methods}

We used wild type moenomycin A (MmA) producer Streptomyces ghanaensis ATCC14672 and its derivatives d_aco and OB21e. In the d_aco mutant a key gene, $a_{c o}$ (ssfg_07849), for butenolide production is disrupted; in OB21e deletion of moeGT1 glycosyltransferase gene completely blocks MmA production [13]. Wild type S. lividans 1326 and its butyrolactone-deficient $s c b A$-mutant were chosen as positive control for root colonization [8]. Agriculturally important mono- and dicotyledonous plants, Hordeum vulgare L. $c v$ Barke (Josef Breun GdbR, Herzogenaurach, Germany) and Lycopersicon esculentum Mill $c v$ MicroTom (Bruno Nebelung GmbH, Everswinkel, Germany), respectively, were used. Prior to bacterial inoculation, the seeds were surface-sterilized as described in [10]. Briefly, after 2-3 days of germination on oatmeal agar plates at $30^{\circ} \mathrm{C}$, the seeds were washed and incubated in either $3 \mathrm{~mL}$ of Streptomyces spore suspension $\left(2,5 \times 10^{9}\right.$ spores $\left./ \mathrm{ml}\right)$ or $3 \mathrm{~mL}$ of $48-\mathrm{h}$ liquid culture broth $(\mathrm{OD}=0,7)$ for $1-1,5 \mathrm{~h}$ [8]. The treated seeds were placed into sterile quartz sand or soil with mineral media (Hoagland's salt). The plants were incubated under $14 \mathrm{~h}$ light, $25^{\circ} \mathrm{C} / 10 \mathrm{~h}$ dark, $20^{\circ} \mathrm{C}$ cycles and $70 \%$ relative humidity [10]. For biometric analyses, two-weeks-old plants were washed from the sand, weight and length of wet shoots and roots were determined (overall we analyzed 36 plants, 6 plants for each strain). The statistical analysis of obtained data was carried out using Sigma Plot ( $t$-test, ANOVA). The root colonization was studied using an established fluoresent in situ hybridization coupled to light scanning microscopy (FISH-LSM) approach [8].

\section{Results and discussion}

In this work we pursued several research directions. First, we tested different approaches towards visualization of MPI. Second, we studied the possibility that secondary metabolism of streptomycetes influence the efficiency of MPI. Third, we explored the influence of model butyrolactone on plant growth parameters. Below we describe our results along these four research lines and discuss the most promising future research directions.

Plant colonization, as portrayed by FISHLSM and reporter beta-glucuronidase gene. All $S$. ghanaensis and S. lividans strains colonized root surface of $H$. vulgare and L. esculentum (Fig. 1). The hybridization signals were mainly located on root hairs. In comparison to mycelial suspensions of $S$. ghanaensis (grown in tryptic soy broth), spore inoculations (harvested from oatmeal agar) provided more extensive colonization of $H$. vulgare roots.
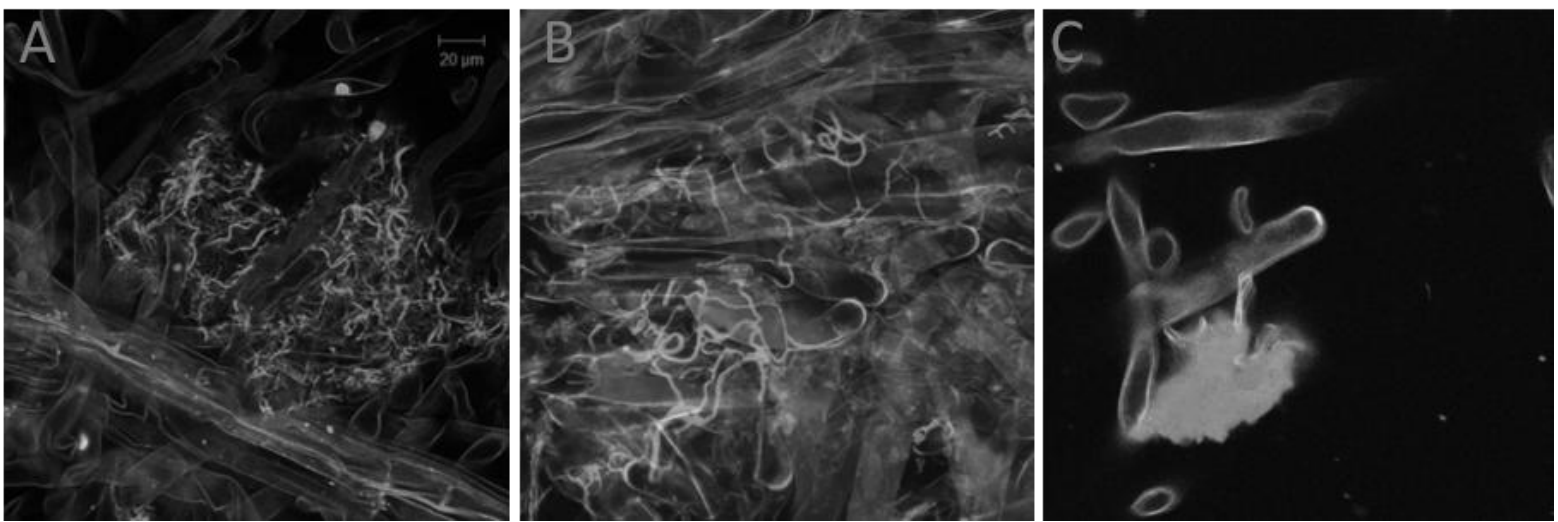

Fig. 1. FISH-LSM-screening of $H$. vulgare and L. esculentum roots colonization by $S$. ghanaensis and S. lividans: A - S. ghanaensis ATCC14672 mycelium on H. vulgare root hairs; B - S. ghanaensis ATCC14672 mycelium on L. esculentum root surface; C - S. lividans M707 mycelium on H. vulgare roots. Pink and blue-violet coloration is a result of fluorescence of two probes - Cy5EUBMix and Cy3HGC69 - owing to overlap of red and green light filters. 
As FISH-LSM is time-consuming, requires expensive reagents and equipment, we therefore explored the possibility to use a Streptomyces codon-adapted $\beta$-glucuronidase reporter gene [14] as a faster and simpler way to detect Streptomyces mycelia in situ. For this purpose reporter plasmid pmoeE5script was used where uidA is fused to AdpA-regulated promoter of hexoisomerase gene moeE5 involved in MmA biosynthesis [15].

An expression of glucuronidase activity from this promoter would therefore be an indicative of $\mathrm{MmA}$ production. The reporter plasmid was transferred conjugally from E. coli ET12567 (pUZ8002) into $S$. ghanaensis strains and spore suspensions of pmoeE5 script $^{+}$transconjugants were used to inoculate plant seeds. Expression of the reporter gene was visualized by soaking the roots in a $2 \mathrm{mM}$ solution of 5-Br-4-Cl-3-indolyl glucuronide (X-Gluc). Plant roots of $H$. vulgare and $L$. esculentum treated with spores of three reporter-containing strains (wild type, d_aco, OB21e) turned blue upon application of X-Gluc solution. Two observations attracted our attention. First, OB21e strain, deficient in $\mathrm{MmA}$ production, colonized the root surface in a patchy pattern, leading to a mix of colorless and blue-colored root areas (Fig. 2). Perhaps, absence of $\mathrm{MmA}$ affects the interaction between the plant and OB21e.
Second, wild type S. ghanaensis colonized the $H$. vulgare roots as well as the d_aco strain did; colonization of $L$. esculentum roots by the aforementioned strains was less intense as compared to $H$. vulgare colonization. These results were reproducible in three independent experiments.

Influence of streptomycetes and simple butyrolactone analogue on plant growth parameters. S. lividans 1326 and scbA strains promoted the growth of $H$. vulgare in an axenic system, but not in soil, while $S$. ghanaensis strains affected $H$. vulgare and L. esculentum biometric parameters under neither condition. In case of S. lividans 1326 and M707, the biomass increase was observed for roots (Fig. 3). Lycopersicon-based experiments revealed no plant growth-promoting activity of Streptomyces.

Bacterial hormones can affect the plant growth as well as inhibit the development of phytopathogens. The simplest analogue of streptomycetes butyrolactones, 1,4-butyrolactone, is known to stimulate the antibiotic production in S. hygroscopicus [16]. In micromolar and low milimolar concentrations this chemical influenced neither MmA production by $S$. ghanaensis nor plant growth. However, at $10 \mathrm{mM}$ it inhibited the shoot and root elongation of L. esculentum.
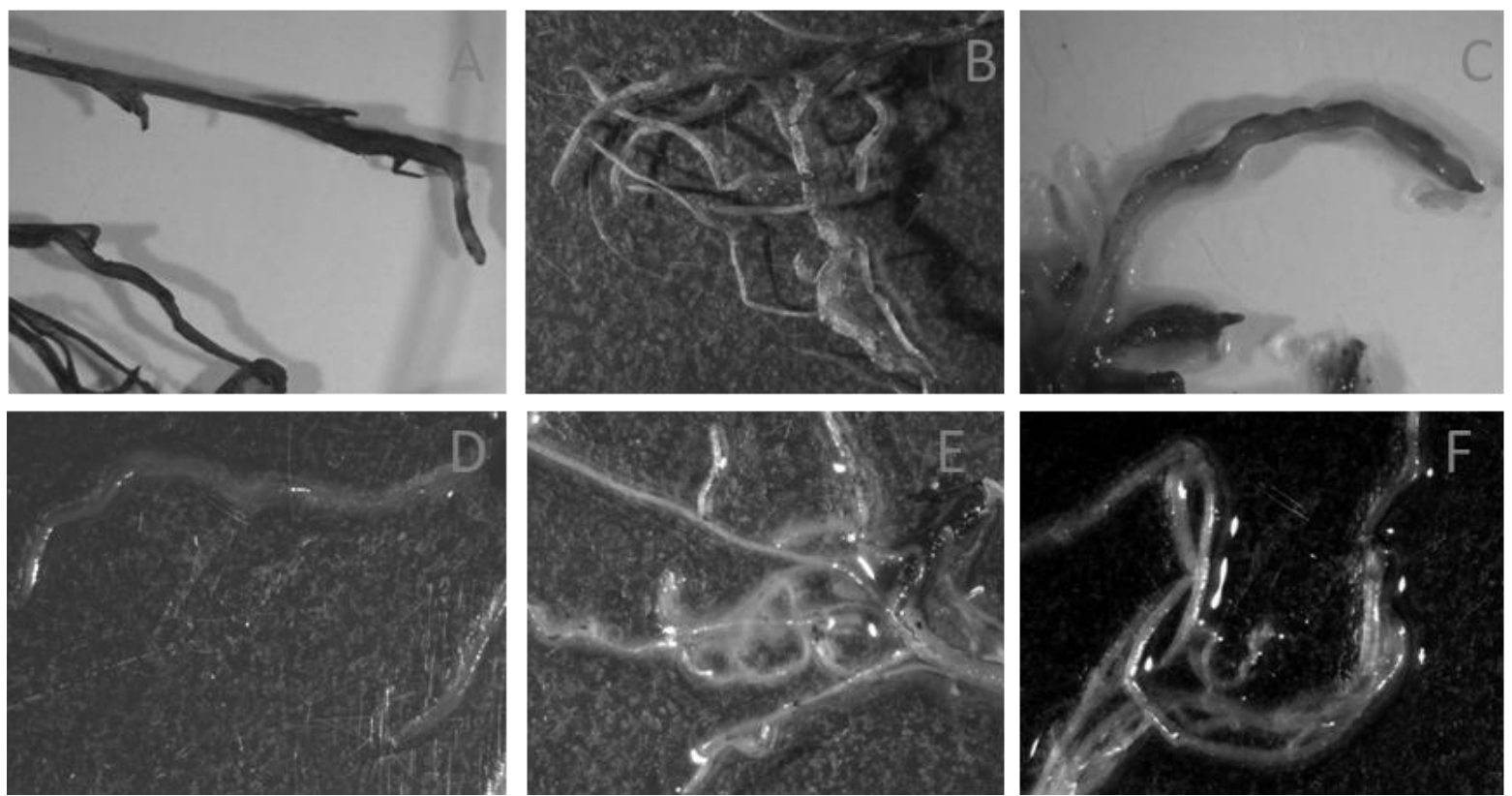

Fig. 2. Glucuronidase screening of $H$. vulgare $(\mathrm{A}, \mathrm{B}, \mathrm{C})$ and L. esculentum (D, E, F) roots colonization by S. ghanaensis strains: A, D - wild type; B, E-d_aco; C, F-OB21E. A blue coloration of root surface is a result of the hydrolysis of X-Gluc to indigo by $\beta$-glucuronidase, which is expressed from a reporter gene in pmoeE5script-carrying streptomycete strains. The photos represent typical result of three independent experiments. 


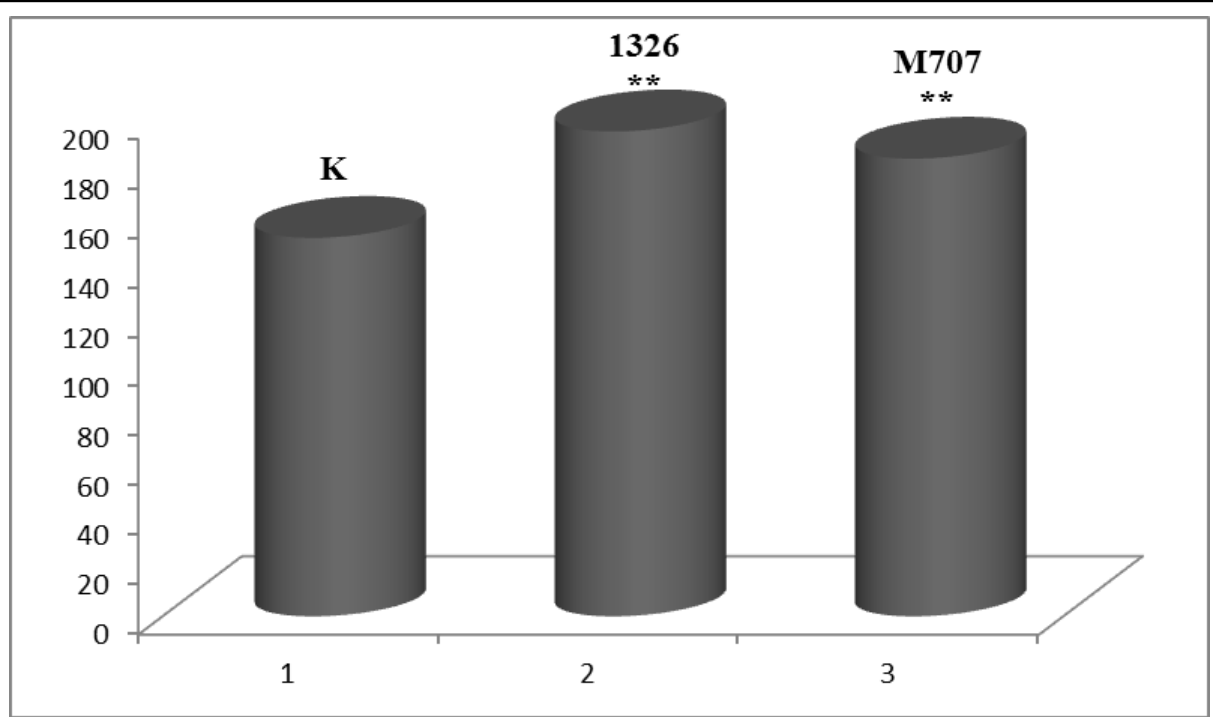

Fig. 3. The weight of roots (vertical axis, mg) of $H$. vulgare plants grown in axenic system from seeds treated with spore suspension of S. lividans 1326 (2) and S. lividans M707 (3); K (1) - untreated control samples. According to $\mathrm{t}$-test ANOVA, the difference in the mean values of the treated groups in comparison to control group, is greater than would be expected by chance ( $\mathrm{p}=0,996$ and $\mathrm{p}=0,991$, respectively); $\mathrm{m}(\mathrm{K})=8,177 ; \mathrm{m}(1326)=10,562 ; \mathrm{m}(\mathrm{M} 707)=8,019$.

\section{Conclusions}

In this work we provided evidence that roots of two practically valuable mono- and dicot plants are colonized by Streptomyces species and showed the utility of reporter gene uidA to monitor the colonization. Secondary metabolism of Streptomyces is believed to be one of the main factors providing a competitive advantage for plants in the form of growth improvement or pathogen suppression [17]. Nevertheless, little evidence exists that streptomycetes indeed are capable of producing antibiotics in rhizosphere or in planta [18]. In our work we used a reporter system based on the promoter of the gene moeE5 essential for initial steps in MmA biosynthesis. The fact that it is "switched on" on root sur- face indirectly implies that antibiotic production could occur there as well. We think that wider application of genetic reporters will help us to better understand the processes of secondary metabolism in rhizosphere, thus portraying a more complete picture of Streptomyces-plant interactions. Finally, we show that low concentrations of butenolide ana$\log$ do not influence plant growth. These results are in agreement with the observation that butenolidedeficient mutant d_aco is not less successful than wild type in its ability to colonize rhizosphere.

H.M. was supported by grant IZKOZ3_154372 from DAAD. This work was supported by grants $B g$ $41 \mathrm{Nr}$ and Bg-46F from Ministry of Education and Science of Ukraine (to B.O. and V.F., respectively).

\section{References}

1. McCormick J., Flardh K. Signals and regulators that govern Streptomyces development. FEMS Microbiol. Rev. 2012. Vol. 36. P. 206-231. doi: 10.1111/j.1574-6976.2011.00317.x.

2. Schrey S., Tarkka M. Friends and foes: streptomycetes as modulators of plant disease and symbiosis. Antonie van Leeuw. 2008. Vol. 94. P. 11-19. doi: 10.1007/s10482-008-9241-3.

3. Kanini G., Katsifas E., Savvides A., Karagouni A. Streptomyces rochei ACTA1551, an indigenous Greek isolate studied as a potential biocontrol agent against Fusarium oxysporum f. sp. lycopersici. BioMed Res. Int. 2013. Vol. 3. P. 1-10. doi: $10.1155 / 2013 / 387230$.

4. Li X., Huang P., Wang Q., Xiao L. Staurosporine from the endophytic Streptomyces sp. strain CNS-42 acts as a potential biocontrol agent and growth elicitor in cucumber. Antonie van Leeuw. 2014. Vol. 106. P. 515-525. doi: 10.1007/s10482-0140220-6.

5. Kim J., Han J., Lee S., Lee D., Hwang I., Kim B. Disease control effect of strevertenes produced by Streptomyces psammoticus against tomato Fusarium wilt. J Agric Food Chem. 2011. Vol. 59. P. 1893-1899. doi: 10.1021/jf1038585.

6. Cao P., Liu C., Sun P., Fu X., Wang S., Wu F., Wang X. An endophytic Streptomyces sp. strain DHV3-2 from diseased root as a potential biocontrol agent against Verticillium dahliae and growth elicitor in tomato (Solanum lycopersicum). Antonie van Leeuw. 2016. Vol. 109. P. 1573-1582. doi: 10.1007/s10482-016-0758-6.

7. Yekkour A., Sabaou N., Zitouni A., Erakhi R., Mathieu F., Lebrihi A. Characterization and antagonistic properties of Streptomyces strains isolated from Saharan soils, and evaluation of their ability to control seedling blight of barley caused by Fusarium culmorum. Lett. Appl. Microbiol. 2012. Vol. 55. P. 427-435. doi: 10.1111/j.1472-765x.2012.03312.x. 
8. Meshke H., Schrempf H. Streptomyces lividans inhibits the proliferation of the fungus Verticillium dahliae on seeds and roots of Arabidopsis thaliana. Microb. Biotechnol. 2010. Vol. 3. P. 428-443. doi: 10.1111/j.1751-7915.2010.00165.x.

9. Meij A., Willemse J., Schneijderberg M., Geurts R., Raaijmakers J., Wezel G. Inter-and intracellular colonization of Arabidopsis roots by endo phytic actinobacteria and the impact of plant hormones on their antimicrobial activity. Antonie van Leeuw. 2018. Vol. 111. P. 679-690. doi: 10.1007/s10482-018-1014-z.

10. Schuhegger R., Ihring A., Gantner S., Bahnweg G. Induction of systemic resistance in tomato by N-acyl-L-homoserine lactone-producing rhizosphere bacteria. Plants Cell and Env. 2006. Vol. 29. P. 909-918. doi: 10.1111/j.1365-3040.2005.01471.x.

11. Willey J., Gaskell A. Morphogenetic signaling molecules of the Streptomycetes. Chem. Rev. 2011. Vol. 111. P. 174-187. doi: $10.1021 /$ cr1000404.

12. Kitani S., Miyamoto K., Takamatsu S., Herawati E., Iguchi H., Nishitomi K., Uchida M., Nagamitsu T. Avenolide, a Streptomyces hormone controlling antibiotic production in Streptomyces avermitilis. Proc. Natl. Acad. Sci. USA. 2011. Vol. 108. P. 16410-16415. doi: 10.1073/pnas.1113908108.

13. Ostash B., Saghatelian A., Walker S. A streamlined metabolic pathway for the biosynthesis of moenomycin. Chem. Biol. 2007. Vol. 14. P. 257-267. doi: 10.101.6/j.chembiol.2007.01.008.

14. Myronovskyi M., Welle E., Fedorenko V., Luzhetskyy A. Beta-glucuronidase as a sensitive and versatile reporter in actinomycetes. Appl. Environ. Microbiol. 2011. Vol. 77. P. 5370-5383. doi: 10.1128/AEM.00434-11.

15. Makitrynskyy R., Ostash B., Tsypik O., Rebets Y., Doud E., Meredith T., Luzhetskyy A., Bechtold A., Walker S., Fedorenko V. Pleiotropic regulatory genes bldA, $a d p A$ and $a b s B$ are implicated in production of phosphoglycolipid antibiotic moenomycin. Open Biol. 2013. Vol. 3. P. 130121. doi: 10.1098/rsob.130121.

16. Tan G., Bai L., Zhang J. Exogenous 1,4-butyrolactone stimulates A-factor-like cascade and validamycin biosynthesis in Streptomyces hygroscopicus 5008. Biotechnol. Bioeng. 2013. Vol. 110. P. 2984-2993. doi: 10.1002/bit.24965.

17. Rey T., Dumas B. Plenty is no plague: Streptomyces symbiosis with crops. Trends Plants Sci. 2017. Vol. 22. P. 30-37. doi: 10.1016/j.tplants.2016.10.008.

18. Schikora A., Schenk S., Stein E., Moliton A., Zuccaro A., Kogel K. N-acyl-homoserine lactone confers resistance toward biotrophic and hemibiotrophic pathogens via altered activation of AtMPK61. Plant Physiol. 2011. Vol. 157. P. $1407-1418$. doi: $10.1104 /$ pp.111.180604.

МУТЕНКО Г. В. ${ }^{1}$, ОСТАШ Б. О. ${ }^{1}$, РОТБОЛЕР М. ${ }^{2}$, ВАЙС А. ${ }^{2}$ ШМІД М. ${ }^{2}$ ГАРТМАН А. ${ }^{2}$, ФЕДОРЕНКО В. О. ${ }^{1}$

${ }^{1}$ Львівський національний університет ім. І. Франка,

Україна, 79005, м. Львів, вул. Грушевського, 4

${ }^{2}$ Група дослідження мікробно-рослинних взаємодій, Мюнхенський иентр Гельмгольиа - Німецький дослідницький иентр стану середовища,

ФРН, Нойгерберг

\section{МІКРОБНО-РОСЛИНН ВЗАЕМОДІЇ МІЖ STREРTOMYCES I МОДЕЛЬНИМИ СІЛЬСЬКОГОСПОДАРСЬКИМИ РОСЛИНАМИ - HORDEUM VULGARE I LYCOPERSICON ESCULENTUM (MICROTOM)}

Mema. Мікробно-рослинні взаємодії (МРВ) - важливий екологічний аспект, унаслідок їхнього суттєвого впливу на здатність рослин протистояти абіотичну стресу та інфекції. Порівняно з протеобактеріями і бацилами, роль стрептоміцетів у МРВ залишається слабо вивченою. У цій роботі ми висвітлили деякі аспекти взаємодії двох модельних видів рослин, Hordeum vulgare і Lycopersicon esculentum, та кількох штамів Streptomyces lividans 1326 i S. ghanaensis АТCC14672. Методu. Було поєднано мікробіологічні, мікроскопічні та молекулярногенетичні підходи для виявлення МРВ. Результати. Показано колонізацію коренів H. vulgare і L. esculentum штамами S. ghanaensis - дикого типу та мутантів з пошкодженою продукцією моеноміцину або сигнальної сполуки $\gamma$-бутиролактонного типу. Обробка насіння $H$. vulgare суспензією спор $S$. lividans викликала зростання біомаси кореня. Рослини, оброблені 1,4-бутиролактоном, не відрізнялися за морфометричними показниками від контролю. Однак, у мілімолярних концентраціях ця сполука пригнічувала ріст коренів і пагонів L. esculentum. Висновки. Корені одно- та дводольних рослин колонізуються бактеріями роду Streptomyces; репортерний ген uidA корисний для моніторингу стрептоміцета на рослині. За використаних умов здатність до колонізації рослин стрептоміцетами не залежала від продукції останніми антибіотиків чи бутеноліду.

Ключові слова: Streptomyces ghanaensis, моеноміцин А, низькомолекулярні сигнальні молекули, колонізація кореня. 